\title{
IMPACT OF WORK AND FAMILY LIFE BALANCE TOWARD CAREER PROGRESSION OF FEMALE LECTURERS IN STATE UNIVERSITIES
}

\author{
R.M.C.S. Ratnayake*, R.M.M.C. Rajapaksha** \\ ${ }^{\mathrm{a}}$ Department of Management Sciences, Faculty of Management, \\ Uva Wellassa University, \\ Badulla, Sri Lanka \\ sajalasachi@gmail.com \\ ${ }^{b}$ Department of Business Management, Faculty of Management Studies, \\ Rajarata University, \\ Mihintale, Sri Lanka \\ medanichanchala123@gmail.com
}

\begin{abstract}
Many female lectures are affected in balancing their work-family life with career progression due to their multiple roles. Organizations were inability to support adequately to female lecturers for balance the multiple roles and poses that make several problems for both employers and employees. This research investigated impact of work and family life balance toward the career progression of female lectures in state universities in Sri Lanka. This is a quantitative research and data collected through questionnaire survey of 150 female lecturers in state universities in Sri Lanka. Purposive sampling technique used to collect data and linear regression, correlation and descriptive statistics were used to analyze data with the tool of SPSS. According to the collected data, family members support play a vital positive role to balance their work life and family life with the career progression. Study revealed that there is an unbalance between work-family life and career progression of female lectures and career progression of female lectures. Researcher recommend to make conscious effort for implement policies for leave and flexible work arrangements for female lecturers.

Key Words: Work-family balance; Career progression; Female lecturers
\end{abstract}

\section{Introduction}

In a South Asian country like Sri Lanka, expected contribution from women are much higher. In day today life, with the responsibilities of females, they face more challenges while in balancing career progression with family life. This rate is higher with married women because they have a lot of obligations towards their husband, children and parents. The importance of career progression and work-life balance cannot be over emphasized. An effective combination of the two makes an individual satisfied. This research study decided to study the State Universities in Sri Lanka. Because there are some lecturers from 8.00 am to 5.00pm in some universities. So their commitment to work life is very high. So that, the challenges they must face in balancing work life with family life is high. And also the time which has to allocate for their studies or career progression is very low. Work-life balance does not hope to accomplish a perfect balance, it is currently believed to help in work satisfaction and career progression. But, there are those who dispute this assertion as it additional or fewer inhibits career progression. this research paper is geared towards searching the worklife balance practices and how it affects female lecturers on State Universities in Sri Lanka and their career progression. That is, if relating with the 'Significant Others' within their human environment will or has helped them achieve absolute growth as they desire in their career or otherwise. The purpose of the study 
is to further broaden our understanding of work-life conflict by examining gender differences in three components of work-life conflict; a. role overload, b. interference from work to family and c. interference from family to work.

Table 1. Labour force participation rate by gender $\%$

\begin{tabular}{lcccc}
\hline Indicator & $\mathbf{2 0 1 4}$ & $\mathbf{2 0 1 5}$ & $\mathbf{2 0 1 6}$ & $\mathbf{2 0 1 7}$ \\
\hline Male & 74.6 & 74.7 & 75.1 & 74.5 \\
\hline Female & 34.6 & 35.9 & 35.9 & 36.6 \\
\hline total & 53.2 & 53.8 & 53.8 & 54.1 \\
\hline Source: Sri
\end{tabular}

Source: Sri Lanka labor force survey- Annual Bulletin 2017

\subsection{Research Objectives}

- To identify the work and family life balance impact on the career progression of female lecturers in state universities in Sri Lanka.

- To identify the impact of work life on the career progression of female lecturers in State Universities in Sri Lanka

- To identify the impact of family life on the career progression of female lecturers in state Universities in Sri Lanka.

\subsection{Research gap and contribution}

In present world, where every individual has to balance conflicting responsibilities and commitments, careerlife balance has emerged as a critical issue in the workplace. Meeting competing demands of career progression and family is not only tiring but also can be stressful and can lead to sickness and absenteeism. It directly affects productivity (Buddhapriya, 2009). Balancing both career and family is an difficult task for working women especially when they have small children and there is no well-equipped day-care/crèche facility where they can leave their kids without any worry while they are at work. Women employees hence face a double burden - work and family — which makes a lot of stress and strain and role conflict. (Buddhapriya, 2009).

University students are the next generation of Executives who going to take over the responsibility of main positions within or outside the country. So, quality of their studying is essential and to maintain the quality of studying, calm/ pleasant mentality of lecturers is a vital factor. Higher level of challenges and inability of managing them cause unhealthy mental and physical conditions. So, the main purpose of this study is to identify the challenges they face when balancing their career progression of work life with family life, reasons for the challenges and propose strategies to overcome those challenges. As a whole, this research study will propose strategies to control the challenges. So, it will help lecturers to,

- Maintain their physical and mental health by facing the challenges successfully

- Maintain a successful career life and family life

- Help to build up quality graduates and achieve the carrier development 


\section{Methodology}

This research study uses the quantitative method as the major approach. Investigative survey was used for this study. An investigative data helped for the find out more information about how work-life balance practices affect for the career progression of female lecturers. Study population was all the female lecturers in State Universities in Sri Lanka. There are 810 female lecturers in State Universities. Among the population 115 female lecturers are used as the sample of the research study. This study used the convenience sampling as the sampling method. Because convenience sampling method not just because it is easy to use, because it also has other research benefits such as, extremely speedy, easy, readily available, and cost effective, causing it to be an attractive option to most researchers. To collect data researcher developed semi structured questionnaire. Reliability and validity of data were measured before the analysis of data by using Cronbach Alpha test and skewness. Data analysis was done through SPSS and for the analysis researcher run the linear regression, correlation. Descriptive statistics were used for the sample profile analysis.

\section{Data Analysis and Presentation}

This research has been carried out using the survey questionnaire in order to obtain information on how the work and family life balance impact on the career progression of female lecturers in state universities in Sri Lanka. Totally 150 female lecturers participated in the survey within five universities in Sri Lanka and the response rate is only $100 \%$. The following section will present the key findings of the research process. This study Cronbach's alpha value is greater than 0.7 . This reliability test concludes the overall reliability of the questionnaire.

Table 2. Reliability statistics for overall model

\begin{tabular}{cc} 
Cronbach's Alpha & N of Items \\
\hline .966 & 3
\end{tabular}

Source: SPSS output from field information (2020)

\subsection{Profile analysis of the sample}

The age of respondents which shows that $38.67 \%$ of the female lecturers are above 45 years of age and only $8 \%$ of female lecturers are having age below 25 years. $88.67 \%$ of female lecturers are married and $11.33 \%$ of female lecturers are single. One child having lecturers are $34.67 \%$ within the sample, $18 \%$ of sample respondents do not have a child in their family, $43.33 \%$ respondents are having two children and only $4 \%$ lecturers are having more than two children in their families. According to the sample collection, $47.33 \%$ respondents' families include four members, $38.67 \%$ respondents are having three member families, $8 \%$ lecturers live with more than four family members in their families and only $6 \%$ of lecturers having two member families. $64.67 \%$ of respondents are live in their own houses, $21.33 \%$ of respondents are live in the rented houses and $14 \%$ of respondents are live with their parent's houses. The education qualifications of the sample respondents. $52 \%$ of respondents are having master degrees, $37.33 \%$ of respondents are PHD holders and only $10.67 \%$ of lecturers are having degree as educational qualification. According to the data analysis, $33.33 \%$ of respondents are having one to five years working experience as a lecturer, $31.33 \%$ of respondents are having more than ten years of working experience in their job, $23.33 \%$ lecturers are experienced in six to 
ten years and only $12 \%$ of lecturers are having less than one year experience as a lecturer.

\subsection{Correlation Analysis}

Table 3. Correlation of work life, family life and career progression

\begin{tabular}{lcc}
\hline & Work Life & Family Life \\
\hline Pearson Correlation & $.914^{* *}$ & $.880^{* *}$ \\
\hline
\end{tabular}

Source: SPSS output from field information (2020)

Correlation between work life and career progression is $0.914(91 \%)$ Which implied that there is a strong positive relationship between work life and career progression. Correlation between family life and career progression is $0.880(88 \%)$ Which implied that there is a strong positive relationship between family life and career progression.

\subsection{Regression Analysis}

$$
\mathrm{CP}=\boldsymbol{\beta} \mathbf{0}+\boldsymbol{\beta} 1 \mathrm{WLB}+\varepsilon
$$

In work and family life and career progression regression test, the constant value is 0.378 and the coefficient of work life balance is 0.900 . It implied that the positive relationship between work life balance and career progression. The R2 value was 0.838 . It can be concluded as $83.80 \%$ of the total variation of career progression is explained by the work life balance. In work life and career progression regression, the constant value is 0.467 and the coefficient of work life is 0.886 . It implied that the positive relationship between work life and career progression. In family life and career progression regression test, the constant value is 0.575 and the coefficient of family life is 0.842 . It implied that the positive relationship between family life and career progression.

\section{Discussion}

According to past researchers' work life balance and career progression, concepts are interconnected, and they have a positive relationship in other sectors and countries. Such as work life balance broadly applied for career progression studies according to the several researchers (Kean, 2002). According to Austin (1984), there is a difference of career progression in women and men and researcher developed different theory for women career progression. Based on the above information the researcher formulated a hypothesis. That hypothesis is interpreted by the linear regression and correlation. According to those interpretations, hypothesis were accepted. It can be summarized as follow;

Table 4. Summary of the hypotheses

\begin{tabular}{llll}
\hline Hypotheses & $\begin{array}{c}\text { Accept / } \\
\text { Reject }\end{array}$ \\
\hline H1 & $\begin{array}{l}\text { There is a positive impact on the career } \\
\text { progression of female lecturers in state } \\
\text { universities in Sri Lanka from work and family }\end{array}$ & Accepted \\
\hline
\end{tabular}




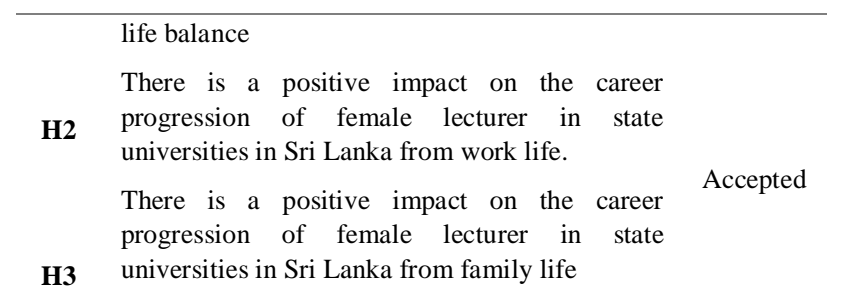

Accepted

Source: Developed by the researcher

According to the findings the researcher found that work life and family life concepts are more collaborating with the career progression of the lecturers. Work life balance and the family life stability are the key points to increase career progression of female lecturers. Analysis denotes that highest values in mean and high values in the Cronbach alpha. Those are the evidence to interpret that these variables have positive impact and significance to the relationship.

According to descriptive analysis, family life is at a rate of high level than the other two variables. However, work life and career progression also at a range of high level. And also, the value of standard deviation for work life, family life and career progression consist of higher deviations from the mean value for each variable. As the outcome of the mean values' female lecturers work life, family life and career progression levels are at a higher level. However, the standard deviation of those are very high, due to that the variation of the data from the mean value is high. It denotes that career progression; work life and family life can vary at any time.

\section{Conclusion}

Work life and career progression according to the sample respondents, the highest rating was strongly agree, which affirms the fact that the families of female lecturers have an impact on their careers, followed by agree, the neutral option, disagree and no response. Most of the respondents (91.4\%) agreed that sometimes they are not able to either take up further studies or take up community services because of their families.

Family life and career progression according to the sample respondents, the highest rating was strongly agree, which affirms the fact that the families of female lecturers have an impact on their careers, followed by agree, the neutral option, disagree and no response. Most of the respondents (88\%) agreed that sometimes they are not able to either take up further studies or take up community services because of their families.

Research findings emphasis that, there is a strong positive relationship between work- family life with career progression of female lecturers. Work life and family life concepts are more collaborating with the career progression of female lecturers.

Finally, the responses given by female lecturers indicate that the many challenges they go through in combining both career and family life inhibit a progression in their career as well as affect their families. Even though work-life balance policies/practices exist in their organization, a more relaxed atmosphere would be a relief since the aim of obtaining the best of or ensuring the best of performance from career mothers cannot be achieved if there is a poor balance between their family life and career. Effective work-life balance ensures progression in one's career. One of the commonly identified factors which affect work life balance of female lecturers is dependent care issues. Lectures with small children face difficulty in their career progression. The other issue is with elder care. Lecturers who face elder care issues found to have more career progression issues than the female lecturers have children.

Another factor which affects career life balance of female lecturers is support network. Support network is positively related with career progression. Moreover, Income level is positively related with career life 
balance. Education level is also positively related. Because when the educated more the can go ahead through their career life.

Base on the findings and conclusion researcher recommend to give leave and flexible work arrangements to enhance their performance of female lecturers, to give flexible time in upgrading themselves academically, to Provide employees with the ability to refuse overtime hours appears to be quite effective in decreasing high role overload. This may reflect the improved ability of such employees to more easily schedule time with family or run errands and recommend a National Policy on Work and Family Life Balance Practices be developed. With the setting up of the Gender Children and Social Change Ministry, it will be a step in the right direction for the ministry to vigorously start considering the issue.

Researcher suggest future researchers to carried out on a large scale in the Region or Country to find out the work-life balance challenges that other women in the corporate world face and how they still development in their career and carry out research into why there are relatively more women in the academia.

\section{References}

Bharathi V., Mala P. \& Bhattacharya S. (2015): Work life balance of women employees in the information technology industry. ASIAN JOURNAL OF MANAGEMENT RESEARCH, Online Open Access publishing platform for Management Research

Buddhapriya S. (2009): Work-Family Challenges and Their Impact on Career Decisions: A Study of Indian Women Professionals. VIKALPA, VOLUME 34

Herath H.M.A (2015): Place of Women in Sri Lankan Society: Measures for Their Empowerment for Development and Good Governance. Journal of Vidyodaya

Clark S. C. \& Farmer P.M.K. (1998): Living in two different worlds: Measuring cultural and value difference between work and home, and their effect on border crossing., Orlando. Paper presented at the Institute of Behavioural and Applied Management Annual Conference

Clark S.C (2000): Work/ Family border theory; a new theory of work or family balance. Journal of Human Relations.

Hsieh Y.C, Pearson T.E. \& Kline S.F. (2008): The Moderating Effects of Job and Personal Life Involvement on the Relationship Between Work-Personal Life Conflict and Intention to Quit. Journal of Human Resources in Hospitality \&amp; Tourism

Kalliath P, Kalliath. T, and Chan C. (2014): Work-Family Conflict and Family-Work Conflict as Predictors of Psychological Strain: Does Social Support Matter? British Journal of Social Work (2015)

Kalliath. P, Kalliath. T, Chan X.W. and Chan C. (2018): Linking Work-Family Enrichment to Job Satisfaction through Job Well-Being and Family Support: A Moderated Mediation Analysis of Social Workers across India. British Journal of Social Work (2018)

Kumari V. (2014): PROBLEMS AND CHALLENGES FACED BY URBAN WORKING WOMEN IN INDIA: independent research study

Opatha H.H.D.N.P., (2019): Sustainable Human Resource Management - Expanding Horizons of HRM (Page 138-201)

Nepali T.N.P. (2018) Balancing Work Life and Family Life: Problems and Remedies. Pravaha Journal

Saltzstein A.L., Ting Y., Saltzstein G.H. (2001): Work-Family Balance and Job Satisfaction: The Impact of Family-Friendly Policies on Attitudes of Federal Government Employees. Public Administration Review

Thompson C.A, Beauvais L.L \& Lyness K.S (1999): When Work-Family Benefits Are Not Enough: The Influence of Work-Family Culture on Benefit Utilization, Organizational Attachment, and Work-Family Conflict. Journal of Vocational Behavior

Valk R, and Srinivasan V. (2011). Work-family balance of Indian women software professionals: A qualitative study. IIMB Management Review

Arunatillake N. (2017) Women in the Sri Lankan Workforce: Dissecting Education and Female Labour Force Participation. "Talking Economics", the blog of the Institute of Policy Studies of Sri Lanka (IPS)

Ermis A. (2018): Women at Work and in the Family: A Discussion on Reconciliation Policy Practices. International Journal of Law, Policy and the Family, 2018

Dindoffer T., Reid B. \& Freed S. (2011): Women Administrators in Christian Universities: Making Family and Career Co-Central. Journal of Research on Christian Education

Kamenou N. (2008): Reconsidering Work-Life Balance Debates: Challenging Limited Understandings of the _Life 'Component in the Context of Ethnic Minority Women's Experiences. British Journal of Management, Vol. 19

Koyuncu M, Burke R.J, Wolpin J. (2012) "Work-family conflict, satisfactions and psychological well-being among women managers and professionals in Turkey", Gender in Management: An International Journal

Saunders M., Lewis P., Thornhill A. (2009): Research methods for business students' fifth edition

Shah V. and Shah P. (2016): WORK - FAMILY BALANCE - A CHALLENGE FOR A WOMEN, Indian Journal of Technical Education (IJTE) | Special Issue for ICWSTCSC-2016

Sorensen T.J and McKim A.J. (2014): Perceived Work-Life Balance Ability, Job Satisfaction, and Professional Commitment among Agriculture Teachers. Journal of Agricultural Education 
Tausig M, \& Fenwick R. (2001): Unbinding time: Alternate Work schedules and WorkLife balance. Journal of Family and Economics Issues

Wheatley D. (2012). Work-life balance, travel-to-work, and the dual career household. A Personnel Review

Greenhaus J. H, Bedian A. G, Mossholder K. W. (1987), Work experiences, job performance, and feelings of personal and family wellbeing, J Voc Behar

Greenhaus, J. H. and Beutell, N. J. (1985), Sources of conflict between work and family roles, Academy of Management

Greenhaus, J. H., and Powell, G. N. (2006), When work and family are allies: A theory of work-family enrichment, Academy of Management 